\title{
ANALISIS SWOT UNTUK PENGEMBANGAN STRATEGI PEMASARAN PRODUK OLAHAN APEL DI MALANG RAYA
}

\author{
Rahayu Relawati, Istis Baroh, Bambang Yudi Ariadi \\ Jurusan Agribisnis Fakultas Pertanian dan Peternakan Universitas Muhammadiyah Malang \\ Email: rahayurelawari.rr@gmail.com
}

\begin{abstract}
This study aimed to carry out a SWOT analysis and formulate marketing strategies of processed apple products. Primary data were obtained from producers and consumers. Producers were selected purposively, while consumers were selected by accidental sampling when they bought the product at souvenirs shops of Malang. SWOT analysis was used to analyze the data taken from both producers and consumers, as well as to formulate marketing strategies. The results showed that in general the products of apple chips, porridge and cider have the strength on products, especially in terms of taste. Meanwhile, the weaknesses are less durable products, however, consumers also do not want any preservatives added. Moreover, the opportunities are the high interest of consumers, many souvenir shops and bank credit offered. On the other side, the threats consists of unhealthy business competition and weakness of consumer purchasing power even though they are interested in the products. Based on the results of the SWOT analysis, marketing strategies recommended to the products of apple chips and apple porridge is aggressive strategy, because they are in the first quadrant of SWOT diagram. Apple cider, however, is recommended to run a defensive strategy, because this product is located in quadrant III of the same diagram. Related promotions, various media information such as local television and internet should be used optimally to promote the products. Consumers should receive the correct and fare information, so that producers must conduct a responsible business ethics.
\end{abstract}

Keywords: SWOT analysis,marketing strategy, processed apple, consumer, producer.

\begin{abstract}
Abstrak: Penelitian ini bertujuan untuk melakukan analisis SWOT dan merumuskan strategi pemasaran produk olahan apel. Data primer diperoleh dari produsen dan konsumen. Produsen dipilih secara purposive, sedangkan konsumen dipilih secara accidental sampling saat mereka membeli produk di toko oleh-oleh khas Malang Raya. Analisis SWOT digunakan untuk menganalisis data produsen dan konsumen, serta untuk merumuskan strategi pemasaran. Hasil penelitian menunjukkan bahwa secara umum produk keripik apel, jenang apel dan sari apel memiliki keunggulan produk terutama dalam hal rasa. Kelemahan yang dimiliki adalah produk kurang tahan lama namun konsumen juga tidak menginginkan adanya bahan pengawet. Peluang yang dihadapi adalah tingginya minat konsumen, banyak toko oleh-oleh dan tawaran kredit bank. Ancaman terdiri dari persaingan bisnis yang tidak sehat dan lemahnya daya beli konsumen meskipun mereka berminat terhadap produk. Berdasarkan hasil SWOT tersebut maka strategi pemasaran yang direkomendasikan pada produk keripik apel dan jenang apel adalah strategi agresif, karena mereka berada di kuadran I diagram SWOT. Sedangkan produk sari apel direkomendasikan menjalankan strategi defensif, karena produk ini berada pada kuadran III diagram yang sama. Terkait promosi, berbagai media informasi seperti televisi lokal dan internet harus digunakan secara optimal untuk kepentingan promosi produk. Konsumen harus menerima informasi yang benar, dengan demikian produsen harus melakukan etika bisnis yang bertanggungjawab.
\end{abstract}

Kata Kunci: Analisis SWOT, strategi pemasaran, olahan apel, konsumen, produsen. 


\section{PENDAHULUAN}

Analsisis SWOT sangat membantu dalam penyusunan strategi pemasaran. Analisis SWOT merupakan penilaian terhadap lingkungan bisnis internal yakni kekuatan (strength) dan kelemahan (weakness), dan lingkungan eksternal yakni peluang (opportunity) dan ancaman (threat) untuk dapat merancang strategi bisnis ke depan (Rangkuti, 2006).

Analisis SWOT telah digunakan pada berbagai bidang dalam pemilihan strategi. Pada bidang agribisnis, analisis SWOT diantaranya ditemukan pada strategi pengembangan jeruk keprok Soe (Namah \& Sinlae, 2012); strategi pengembangan industri jagung (Wan-rong et al., 2013); dan strategi pengembangan agribisnis (Darmansyah, Rochana, Sutardi, \& Zuraida, 2014). Penelitian mereka tidak secara fokus untuk merumuskan strategi pemasaran komoditi yang diteliti.

Analisis SWOT yang fokus pada strategi pemasaran ditemukan pada komoditi nonagribisnis yakni User Centred Process (Ioan \& Cristin, 2014); valuta asing (Shariatmadari, Homayoun, \& Hedayat, 2013). Penelitian tersebut dilakukan pada perusahaan besar. Sedangkan pada Usaha Kecil Menengah (UKM) bidang agribisnis belum ditemukan implementasi analisis SWOT.

Apel (Malus sylvestris Mill) merupakan komoditas buah yang memiliki peranan penting bagi pertanian di Kota Batu dan Kabupaten Malang. Apel dikonsumsi terutama dalam bentuk segar sebagai sumber vitamin dan serat. Bentuk olahannya yang saat ini sudah populer adalah keripik, jenang, dan sari apel. Produk olahan apel semakin diminati, karena konsumen semakin menyukai olahan apel sebagai oleh-oleh untuk dibawa ke luar kota karena praktis, ringan dan relatif lebih awet dibandingkan apel segar.

Analisis SWOT belum ditemukan pada strategi pemasaran produk olahan apel, padahal ini sangat penting dalam keputusan penentuan strategi pemasaran mereka. Referensi strategi pemasaran produk olahan apel penting bagi pelaku UKM bidang makanan dan minuman, khususnya yang berbasis apel lokal dalam memenangkan persaingan pasar.

Saat ini para pelaku usaha olahan apel dihadapkan pada kompetisi dengan sesama produsen olahan makanan, dengan bahan dari apel atau lainnya. Pada umumnya strategi pemasaran mereka dilakukan tanpa penilaian secara sistematis terhadap keunggulan pesaing. Padahal menurut Porter, pengembangan strategi pemasaran seharusnya menggunakan konsep strategi penguatan keunggulan bersaing atau competitive advantages (Porter, 1998). Jadi, pemberdayaan terhadap UKM olahan apel saat ini sangat dibutuhkan. Oleh karena itu penting dilakukan penelitian analisis SWOT untuk merumuskan strategi pemasaran produk olahan apel. Tujuan penelitian adalah untuk menganalisis kekuatan dan kelemahan produk olahan sari apel berdasarkan penilaian konsumen dan produsen, peluang dan ancaman berdasarkan penilaian produsen, serta merumuskan strategi pemasaran olahan apel berdasarkan hasil analisis SWOT.

Kebaruan yang ditawarkan dalam penelitian ini adalah penggabungan antara penilaian konsumen dan penilaian produsen dalam pemilihan indikator kekuatan dan kelemahan, serta bobot dan skor pada indikator tersebut. Sedangkan indikator peluang dan ancaman, serta bobot dan ratingnya didasarkan pada penilaian produsen.

\section{METODE PENELITIAN}

Tempat penelitian adalah di Kota Batu dan Kota Malang (Jawa Timur), secara umum disebut sebagai daerah Malang Raya. Jenis data yang digunakan adalah data primer yang diperoleh dari responden pelaku usaha olahan apel dan konsumen produk olahan apel, pada rentang waktu bulan Januari hingga Maret 2015. Teknik pengumpulan data dilakukan dengan wawancara terstruktur dengan konsumen dan wawancara mendalam dengan pengusaha olahan apel.

Pengambilan sampel konsumen dilakukan dengan accidental sampling, yakni pengambilan sampel konsumen yang secara kebetulan dijumpai (Bhattacherjee, 2012) saat melakukan pembelian produk olahan apel di toko oleh-oleh. Jumlah sampel konsumen sebanyak 90 orang, terdiri dari masingmasing 30 orang konsumen keripik apel, jenang apel dan sari apel. Mereka diwawancarai tentang penilaian mereka terhadap produk, harga, tempat, dan promosi produk olahan apel, mengacu pada konsep 
marketing mix (Kotler \& Armstrong, 2012). Hasil penilaian konsumen dijadikan sebagai dasar untuk menentukan kekuatan dan kelemahan produk olahan apel, dalam analisis SWOT (Rangkuti, 2006).

Responden produsen olahan apel dipilih secara sengaja berdasarkan kesediaan, yakni satu orang produsen kripik apel di Kota Malang dan satu produsen sari apel dan jenang apel di Kota Batu. Mereka diwawancarai tentang lingkungan bisnis internal (kekuatan dan kelemahan), serta lingkungan ektsternal (peluang dan ancaman).

Analisis SWOT dilakukan berdasarkan data primer yang diperoleh dari konsumen dan dari produsen. Responden konsumen memberikan penilaian tentang atribut kualitas produk olahan apel dengan skala Likert rentang 1 sampai 5. Produsen memberikan jawaban uraian secara kualitatif tentang data lingkungan internal dan eksternal usaha olahan apel berdasarkan pengalaman yang dilalui, hasilnya disajikan secara naratif dan diringkas untuk menemukan indikator SWOT. Selanjutnya langkah penentuan indikator SWOT, bobot dan skor adalah sebagai berikut:

- Indikator kekuatan dan kelemahan ditetapkan berdasarkan penilaian konsumen dan produsen

- Kekuatan produk jika rata-rata penilaian konsumen 3,8 atau lebih dan atau penilaian produsen

- Kelemahan produk jika rata-rata penilaian konsumen 3,0 atau dan atau penilaian produsen

- Indikator peluang dan ancaman ditetapkan berdasarkan penilaian produsen

- Penentuan bobot dari masing-masing indikator mula-mula total bobot 1 (satu) dibagi rata pada sejumlah indikator yang ditemukan. Selanjutnya indikator kekuatan/ kelemahan yang esensinya sama yang bersumber dari penilaian konsumen dan produsen diberi bobot lebih, dengan mengurangki bobot indikator yang hanya bersumber dari konsumen saja atau produsen saja. Sehingga, total bobot tetap satu atau $100 \%$.

- Skor (rating) ditetapkan berdasarkan urgensi pemecahan masalah, yang terpenting diberi skor 4, yang kurang penting 3 dan seterusnya. Informasi tingkat kepentingan diperoleh dari responden produsen olahan apel.

Hasil analisis SWOT dideskripsikan dalam diagram SWOT, yang menunjukkan posisi bisnis olahan apel berada pada kuadran mana dan berimplikasi pada strategi umum yang harus dilakukan. Strategi bisnis yang harus dilakukan sesuai pada posisi kuadran I, II, III, IV masing-masing adalah: agresif, diversifikasi, bertahan, dan pengembangan (Rangkuti, 2006).

\section{HASIL DAN PEMBAHASAN}

Deskripsi hasil penelitian meliputi hasil penilaian konsumen terhadap indikator marketing mix, analisis SWOT dari konsumen dan produsen, diagram SWOT, dan dilanjutkan dengan strategi pemasaran yang direkomendasikan berdasarkan hasil analisis SWOT.

\section{Penilaian konsumen terhadap indikator marketing mix}

Penilaian konsumen terhadap indikator marketing mix secara visual dapat dilihat pada gambar 1. Indikator marketing mix dengan nilai rata-rata minimal 4 berarti mendapatkan nilai baik dan sangat baik atau enak dan sangat enak. Oleh karena itu nilai rata-rata minimal 4 ditetapkan sebagai indikator kekuatan. Dengan kriteria ini indikator kekuatan hanya dimiliki produk keripik dan jenang apel saja, ada delapan indikator. Jika batas nilai diturunkan menjadi 3,8 maka produk sari apel mendapatkan satu indikator kekuatan yakni rasa, dengan demikian indikator kekuatan produk keripik apel dan jenang apel juga bertambah.

Indikator marketing mix dengan nilai rata-rata maksimal tiga ditetapkan sebagai kelemahan yang berasal dari penilaian konsumen. Dengan batas ini, produk jenang apel dan sari apel masing-masing mendapatkan dua indikator kelemahan, sedangkan produk keripik apel mendapatkan satu indikator kelemahan. 


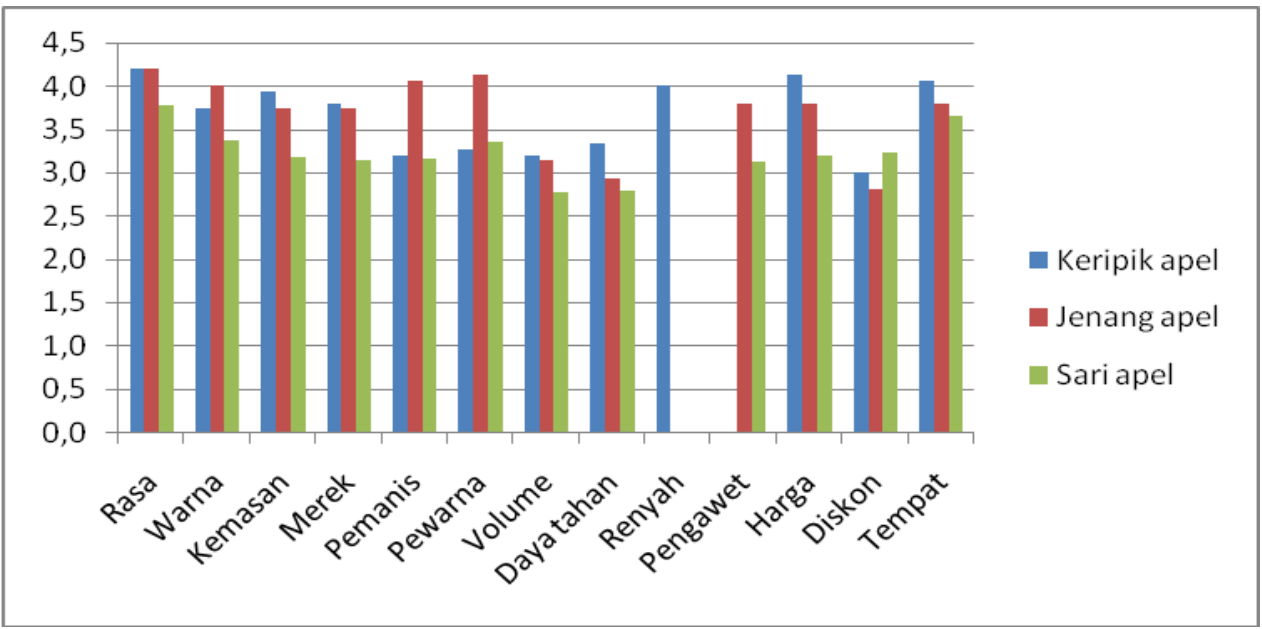

Grafik 1. Nilai rata-rata atribut produk, harga dan tempat pembelian olahan apel

Tabel 1. Nilai rata-rata penilaian konsumen terhadap atribut olahan apel untuk menentukan kekuatan atau kelemahan

\begin{tabular}{|c|c|c|c|c|c|c|}
\hline \multirow[t]{2}{*}{ Atribut kualitas apel } & \multicolumn{2}{|c|}{ Keripik apel } & \multicolumn{2}{|c|}{ Jenang apel } & \multicolumn{2}{|c|}{ Sari apel } \\
\hline & $\begin{array}{l}\text { Nilai rata- } \\
\text { rata }\end{array}$ & $\begin{array}{l}\text { Strength / } \\
\text { Weakness }\end{array}$ & $\begin{array}{l}\text { Nilai rata- } \\
\text { rata }\end{array}$ & $\begin{array}{l}\text { Strength / } \\
\text { Weakness }\end{array}$ & $\begin{array}{l}\text { Nilai rata- } \\
\text { rata }\end{array}$ & $\begin{array}{l}\text { Strength / } \\
\text { Weakness }\end{array}$ \\
\hline Rasa & 4.2 & SK1 & 4.2 & SK1 & 3.8 & SK1 \\
\hline Warna & 3.7 & & 4.0 & SK2 & 3.4 & \\
\hline Kemasan & 3.9 & SK2 & 3.7 & & 3.2 & \\
\hline Merek & 3.8 & SK3 & 3.7 & & 3.1 & \\
\hline Pemanis aman & 3.2 & & 4.1 & SK3 & 3.2 & \\
\hline Pewarna aman & 3.3 & & 4.1 & SK4 & 3.4 & \\
\hline Volume & 3.2 & & 3.1 & & 2.8 & WK1 \\
\hline Daya tahan & 3.3 & & 2.9 & WK1 & 2.8 & WK2 \\
\hline Renyah & 4.0 & SK4 & & & & \\
\hline Pengawet aman & & & 3.8 & SK5 & 3.1 & \\
\hline Harga & 4.1 & SK5 & 3.8 & SK6 & 3.2 & \\
\hline Diskon & 3.0 & WK1 & 2.8 & WK2 & 3.2 & \\
\hline Tempat & 4.1 & SK6 & 3.8 & SK7 & 3.7 & \\
\hline
\end{tabular}

\section{Keterangan:}

Kekuatan (Strength) : nilai rata-rata 3,8 atau lebih

SK

: Strength dari penilaian konsumen

Kelemahan (Weakness) : nilai rata-rata 3,0 atau kurang

WK

: Weakness dari penilaian konsumen

\section{Penilaian produsen terhadap lingkungan bisnis internal dan eksternal}

\subsection{Produsen keripik apel}

Sumber informasi analisis SWOT dari pengusaha adalah pemilik UD Virgo Snack Bersinar di Kota Malang. UD ini memproduksi aneka kripik buah, yang paling rutin adalah kripik apel karena bahan baku tersedia sepanjang tahun. Menurut pemilik usaha ini kekuatan usaha aneka kripik buah dibandingkan dengan usaha yang sama milik pengusaha lain adalah: kualitas produk lebih baik, diberi kode SP 1 (strength produsen nomor 1). Kekuatan lainnya adalah harga terjangkau (SP2) dan pelayanan yang baik oleh usaha ini terutama dalam pemasaran (SP3). Usaha ini bersedia mengirimkan produk sesuai pesanan dan diantar sampai ke tempat terutama pada pelanggan yang sudah dikenal.

Sementara itu kelemahan yang dimiliki usaha ini dibanding produksi pengusaha lain adalah kapasitas mesin yang masih kecil (weakness produsen nomor $1=$ WP1). Pemilik merasa bahwa kapasitas usahanya masih terbatas dan belum memenuhi peluang pasar yang ada karena kapasitas mesin yang dimiliki masih kurang. Walaupun faktanya usaha ini 
sudah memiliki mesin vacum frying dengan kapasitas $25 \mathrm{~kg}$ sebanyak 4 unit, namun kecepatan produksi dirasakan masih lambat.

Peluang yang masih memungkinkan untuk diraih usaha ini adalah: adanya kredit bank (O1) dan tingginya minat konsumen $(\mathrm{O} 2)$ terhadap produk olahan apel, dapat dilihat dari terus meningkatnya permintaan konsumen. Beberapa bank menawarkan kredit, tentu karena melihat prospek usaha ini cukup bagus. Tingginya minat konsumen terindikasi dari jumlah permintaan makin banyak sehingga tidak semua terpenuhi dan makin luasnya daerah yang harus dikirimi produk. Saat ini jangkauan pasar terjauh adalah Denpasar-Bali.

Masih menurut pengusahanya, ancaman yang dianggap mengganggu perkembangan usaha adalah: persaingan bisnis serupa (T1) dan lemahnya daya beli konsumen (T2). Bisnis olahan apel makin bermunculan dengan berbagai kapasitasnya. Banyak bermunculan produsen baru dengan kapasitas kecil, karena mereka melihat prospek bisnis ini cukup baik.

\subsection{Produsen jenang apel dan sari apel}

Sumber informasi analisis SWOT dari pengusaha adalah pemilik Bagus Agriseta Mandiri yang memproduksi jenang apel dan sari apel. Pengusaha ini memproduksi jenang apel, jenang buah lainnya, dan sari apel. Dalam penelitian ini yang dibahas adalah produk olahan apel saja (jenang apel dan sari apel). Menurut pemilik usaha ini kekuatan usaha jenang dan sari apel dibandingkan dengan usaha yang sama milik pengusaha lain adalah: menggunakan gula murni (SP1), menggunakan buah asli dengan rasa asli buah (SP2), proses higienis (SP3) dan kandungan gizi tinggi (SP4). Alasan pemilik usaha ini menjawab demikian adalah banyaknya usaha yang sama dan terdorong oleh rasa ingin memenangkan persaingan sering mendorong produsen makanan dan minuman olahan untuk memakai bahan-bahan pemanis dan atau perasa buatan yang sebenarnya tidak sehat. Hal ini dilakukan untuk memungkinkan biaya produksi rendah sehingga mereka mampu bersaing dengan menjual produk murah namun memperoleh keuntungan yang tinggi.

Sementara itu kelemahan yang dimiliki usaha jenang apel dan sari apel dibanding produksi produsen lainnya adalah: harga jual lebih tinggi (WP1) dan jaringan pemasaran masih relatif terbatas (WP2). Pengusaha menjelaskan bahwa dengan menggunakan bahan asli apel sebagai bahan jenang apel dan minuman sari apel maka jumlah apel yang digunakan per satuan produk menjadi lebih banyak, sehingga mereka tidak mungkin menekan biaya produksi. Oleh karena itu harga jual produknya terutama sari apel jauh lebih tinggi (WP3) dari produk yang sama dari merek lain. Karena mahalnya produk ini maka segmen pasar produk juga relatif pada kelompok menengah dan ini berkonsekuensi pada terbatasnya jangkauan pemasaran.

Peluang yang masih memungkinkan untuk diraih usaha ini adalah: potensi kota sebagai kota wisata yang banyak mendatangkan wisatawan (O3). Seiring tumbuhnya kota wisata (Batu) maka usaha pusat makanan jajanan (oleh-oleh) juga bermunculan. Hampir di setiap jalan raya strategis terutama jalur menuju keluar kota dapat dipastikan ada toko oleh-oleh khas Malang Raya. Bagi produsen olahan dodol dan sari apel, banyaknya toko oleh-oleh (O4) memudahkan pemasaran produknya. Peluang lainnya adalah adanya bantuan pemerintah dalam bentuk membuka jaringan kemitraan (O5) pemasaran.

Ancaman adalah hal-hal yang terjadi di luar usaha yang sifatnya mengancam usaha. Menurut produsen jenang apel dan sari apel ancaman yang dihadapi adalah persaingan bisnis serupa yang kurang sehat (T3).

\section{Analisis Faktor Internal (IFAS)}

Analisis faktor kekuatan dan kelemahan bersumber dari data penilaian konsumen dan penilaian produsen. Masing-masing hasil penilaian kekuatan oleh konsumen yang diberi kode SK dan hasil penilaian kekuatan oleh produsen yang diberi kode SP, setelah digabungkan menjadi satu indikator kekuatan diberi kode S1, S2 dan seterusnya.

Demikian juga masing-masing hasil penilaian kelemahan oleh konsumen yang diberi kode WK dan hasil penilaian kelemahan oleh produsen yang diberi kode WP, setelah digabungkan menjadi satu indikator kelemahan diberi kode W1, W2 dan seterusnya. 
Rahayu R., Istis B., Bambang Y. A. : Analisis Swot Untuk Pengembangan Strategi ...

Tabel 2. Rekap penilaian produsen terhadap SWOT produk olahan apel

\begin{tabular}{|c|c|c|}
\hline $\begin{array}{l}\text { Indikator } \\
\text { SWOT }\end{array}$ & Kripik apel & Jenang apel dan sari apel \\
\hline Kekuatan & $\begin{array}{l}\text { Kualitas produk (SP1) } \\
\text { Harga terjangkau (SP2) } \\
\text { Pelayanan baik (SP3) }\end{array}$ & $\begin{array}{l}\text { Menggunakan gula murni (SP1), } \\
\text { Menggunakan buah asli (SP2), Proses } \\
\text { higienis (SP3) } \\
\text { Kandungan gizi tinggi (SP4) }\end{array}$ \\
\hline Kelemahan & kapasitas mesin kecil (WP1) & $\begin{array}{l}\text { Harga jual lebih tinggi (WP1) } \\
\text { Jaringan pemasaran terbatas (WP2) }\end{array}$ \\
\hline Peluang & $\begin{array}{l}\text { Adanya kredit bank }(\mathrm{O} 1) \\
\text { Tingginya minat konsumen }(\mathrm{O} 2)\end{array}$ & $\begin{array}{l}\text { Potensi sebagai kota wisata mendatangkan } \\
\text { banyak wisatawan }(\mathrm{O} 3) \\
\text { Banyaknya toko oleh-oleh }(\mathrm{O} 4) \\
\text { Jaringan kemitraan }(\mathrm{O} 5)\end{array}$ \\
\hline Ancaman & $\begin{array}{l}\text { Persaingan bisnis serupa (T1) } \\
\text { Lemahnya daya beli konsumen (T2) }\end{array}$ & $\begin{array}{l}\text { Persaingan bisnis serupa yang kurang sehat } \\
\text { (T3) }\end{array}$ \\
\hline
\end{tabular}

Tabel 3. Analisis faktor internal (IFAS) produk kripik apel

\begin{tabular}{|c|c|c|c|}
\hline Faktor strategis internal & Bobot & Skor & Bobot x Skor \\
\hline \multicolumn{4}{|l|}{ Kekuatan (Strength) } \\
\hline Rasa $(\mathrm{SK} 1+\mathrm{SP} 1)$ & 0.20 & 4 & 0.80 \\
\hline Kemasan (SK2) ............................... S2 & 0.10 & 3 & 0.30 \\
\hline 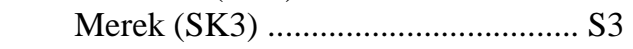 & 0.10 & 3 & 0.30 \\
\hline Kerenyahan $(\mathrm{SK} 4+\mathrm{SP} 1) \ldots \ldots \ldots \ldots \ldots . . . \mathrm{S} 4$ & 0.20 & 4 & 0.80 \\
\hline Harga $($ SK5 + SP2) ............................ S5 & 0.20 & 4 & 0.80 \\
\hline Tempat pembelian $(\mathrm{SK} 6+\mathrm{SP} 3) \ldots . . . \mathrm{S} 6$ & 0.20 & 3 & 0.60 \\
\hline Jumlah & 1,00 & & 3,60 \\
\hline \multicolumn{4}{|l|}{ Kelemahan (Weakness) } \\
\hline Tidak/jarang ada diskon (WK1) ......W1 & 0,50 & 3 & 1,50 \\
\hline Kapasitas mesin kecil (WP1)..........W2 & 0,50 & 3 & 1,50 \\
\hline Jumlah & 1,00 & & 3,0 \\
\hline
\end{tabular}

Selisih antara kekuatan dengan kelemahan sebesar $+0,50$.

Keterangan: Faktor strategis internal bersumber dari tabel 1 dan tabel 2.

Selanjutnya untuk menggabungkan penilaian produsen dan penilaian konsumen dalam analisis SWOT dilakukan pembobotan dan pemberian skor/rating. Total bobot $100 \%$ dibagi sejumlah item kekuatan, misalkan untuk keripik apel ada enam item kekuatan berdasarkan penilaian konsumen dan tiga kekuatan berdasarkan penilaian produsen. Penilaian kedua pihak sumber data tersebut dapat digabungkan karena esensinya sama. Total bobot $1(100 \%)$ dibagi enam sebesar 0,167 . Item kekuatan yang bersumber dari jawaban konsumen sekaligus produsen diberi bobot lebih besar dari item kekuatan yang bersumber hanya dari salah satu pihak.

Skor (rating) ditetapkan berdasarkan urgensi pemecahan masalah, yang terpenting diberi skor 4 , yang kurang penting 3 dan seterusnya. Informasi tersebut diperoleh dari responden pelaku usaha olahan apel. Hasil akhir penentuan bobot dan skor analisis SWOT dapat dilihat pada tabel 3 (keripik apel), tabel 4 (jenang apel), dan tabel 5 (sari apel).

3.1.Kekuatan dan kelemahan produk keripik apel

Produk keripik apel mempunyai enam kekuatan (S1 sampai S6). Empat diantara kekuatan tersebut melekat pada produk, yakni: rasa, kemasan, merek, dan kerenyahan. Kekuatan lainnya terletak pada harga yang terjangkau dan tempat pembelian yang bersih dan nyaman. Sedangkan kelemahan yang dimiliki adalah tidak ada atau jarang ada diskon. Berdasarkan hasil analisis IFAS, selisih antara skor kekuatan dan kelemahan sebesar $(+0,60)$. 
Indikator marketing mix lainnya adalah promosi atau sumber informasi tentang produk. Mayoritas responden (80\%) menerima sumber informasi tentang keripik apel dan khususnya merek tertentu secara lisan. Sumber informasi yang dominan adalah dari teman $(47 \%)$ diikuti kerabat $(27 \%)$ dan tetangga $(7 \%)$. Diantara mereka hanya $20 \%$ saja yang menerima sumber informasi dari promosi, itupun bukan selalu tentang merek yang dibeli. Misalnya mereka membaca majalah wisata tentang Kota Malang dan Kota Batu atau menelusur internet tentang produk oleh-oleh khas Malang.

3.2.Kekuatan dan kelemahan produk jenang apel

Produk jenang apel mempunyai enam kekuatan, semuanya melekat pada produk. Sedangkan aspek marketing mix lainnya (harga dan tempat) tidak menjadi aspek kekuatan. Kelemahan produk adalah tidak awet, harganya relatif mahal dan jaringan pemasaran terbatas.

Terkait sumber informasi produk, mayoritas responden $(53 \%)$ menerima sumber informasi tentang jenang apel dan khususnya merek tertentu secara lisan. Sumber informasi yang dominan adalah dari kerabat $(33 \%)$ diikuti teman (13\%) dan tetangga (7\%). Cukup menarik disini bahwa responden konsumen jenang apel sebanyak 47\% menerima sumber informasi dari promosi, meskipun bukan selalu tentang merek yang dibeli. Misalnya mereka melihat pameran produk, browsing internet atau melihat acara di telivisi lokal tentang produk unggulan setempat.

\subsection{Kekuatan dan kelemahan produk sari apel}

Diantara ketiga produk olahan apel, sari apel memiliki kekuatan yang sangat terbatas menurut penilaian konsumen, yakni hanya dalam hal rasa. Mereka menilai dari segi rasa, sari apel enak dan segar. Beberapa indikator produk lainnya justru menjadi kelemahan, yakni volume, tidak awet dan penggunaan bahan pengawet. Dibandingkan dengan harganya, volume kemasan produk (140 ml per cup), tiap kardus isi 30 cup dianggap terlalu kecil. Pihak produsen juga mengakui harga produknya yang lebih mahal dibandingkan lainnya. Konsumen juga menilai produk minuman ini tidak awet untuk konsumsi jangka panjang atau untuk oleh-oleh dibawa keluar kota. Namun mereka juga tidak menginginkan sari apel diberi pengawet yang berbahaya, mereka bahkan memberikan skor rendah untuk bahan pengawet minuman ini. Kelemahan produk ini menurut produsen adalah harga lebih tinggi dan jaringan pasar masih terbatas. Responden konsumen sari apel sebanyak 57\% menerima informasi produk secara lisan. Rinciannya adalah 37\% dari teman, $10 \%$ kerabat, dan $10 \%$ tetangga. Sebanyak $43 \%$ konsumen menerima informasi dari promosi. Maksud promosi adalah informasi dari sumber resmi tentang produk olahan apel dari Batu dan Malang, terutama dari media internet dan televisi lokal di Malang Raya.

Tabel 4. Analisis faktor internal (IFAS) produk jenang apel

\begin{tabular}{|c|c|c|c|}
\hline Faktor strategis internal & Bobot $(\%)$ & Skor & Bobot x Skor \\
\hline \multicolumn{4}{|l|}{ Kekuatan (Strength): } \\
\hline Rasa enak (SK1) + buah asli (SP2) ......... S1 & 0.20 & 4 & 0,80 \\
\hline Warna menarik (SK2) ………................. S2 & 0.15 & 3 & 0,60 \\
\hline Pemanis aman (SK3) + gula murni (SP1).S3 & 0.20 & 4 & 0,80 \\
\hline 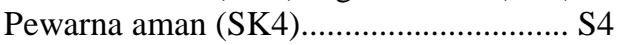 & 0.15 & 3 & 0,45 \\
\hline 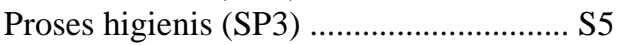 & 0.15 & 4 & 0,60 \\
\hline Kandungan gizi tinggi (SP4) ................... S6 & 0.15 & 3 & 0,45 \\
\hline Jumlah & 1,00 & & 3,70 \\
\hline \multicolumn{4}{|l|}{ Kelemahan (Weakness) } \\
\hline Daya Tahan (WK1) ......... & 0,25 & 2 & 0,50 \\
\hline Tidak diskon (WK2), harga tinggi (WP1).S2 & 0,40 & 3 & 1,20 \\
\hline Jaringan pemasaran terbatas (WP2) .........S3 & 0,35 & 4 & 1,40 \\
\hline Jumlah & 1,00 & & 3,20 \\
\hline
\end{tabular}

Selisih antara kekuatan terhadap kelemahan sebesar +50

Keterangan: Faktor strategis internal bersumber dari tabel 1 dan tabel 2. 
Rahayu R., Istis B., Bambang Y. A. : Analisis Swot Untuk Pengembangan Strategi ...

Tabel 5. Analisis faktor internal (IFAS) produk sari apel

\begin{tabular}{|c|c|c|c|}
\hline Faktor strategis internal & Bobot $(\%)$ & Skor & Bobot x Skor \\
\hline \multicolumn{4}{|l|}{ Kekuatan (Strength) } \\
\hline Rasa enak (SK1) + buah asli (SP2) ....... S1 & 0,30 & 4 & 1,20 \\
\hline Menggunakan gula murni (SP1).............S2 & 0,20 & 3 & 0,60 \\
\hline Proses higienis (SP3) .............................. S3 & 0,20 & 3 & 0,60 \\
\hline \multirow[t]{2}{*}{ Kandungan gizi tinggi (SP4) .................. S4 } & 0,20 & 3 & 0,60 \\
\hline & 1.00 & & 3,00 \\
\hline \multicolumn{4}{|l|}{ Kelemahan (Weakness) } \\
\hline 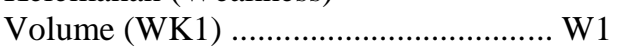 & 0,25 & 3 & 0,75 \\
\hline Daya tahan (WK2) ...........................W2 & 0,25 & 3 & 0,75 \\
\hline Harga lebih tinggi (WP1) .......................W3 & 0,25 & 4 & 1,00 \\
\hline Jaringan pasar terbatas (WP2) ..... & 0,25 & 4 & 1,00 \\
\hline Jumlah & 1.00 & & 3,50 \\
\hline
\end{tabular}

Selisih antara kekuatan dan kelemahan sebesar -0,50

Keterangan: Faktor strategis internal bersumber dari tabel 1 dan tabel 2.

Tabel 6. Analisis faktor eksternal (EFAS) produk kripik, jenang dan sari apel

\begin{tabular}{|c|c|c|c|}
\hline Faktor strategis eksternal & Bobot $(\%)$ & Skor & Bobot x Skor \\
\hline \multicolumn{4}{|l|}{ Peluang (Opportunity) } \\
\hline Banyaknya tawaran kredit bank .......... O1 & 0,17 & 3 & 0,51 \\
\hline Tingginya minat konsumen ................. O2 & 0,22 & 4 & 0,88 \\
\hline Banyaknya wisatawan .......................... O3 & 0,22 & 4 & 0,88 \\
\hline Banyaknya pusat oleh-oleh ................... O4 & 0,22 & 4 & 0,88 \\
\hline \multirow[t]{2}{*}{ Terbukanya jaringan kemitraan ........... O5 } & 0,17 & 4 & 0,68 \\
\hline & 100 & & 3,83 \\
\hline \multicolumn{4}{|l|}{ Ancaman (Threat) } \\
\hline Persaingan bisnis yang tidak sehat ....... T1 & 0,50 & 4 & 2,00 \\
\hline Lemahnya daya beli konsumen ............T2 & 0,50 & 3 & 1,00 \\
\hline Jumlah & 100 & & 3,00 \\
\hline
\end{tabular}

Selisih nilai antara peluang dan ancaman sebesar $+0,83$

\section{Analisis Faktor Eksternal (EFAS)}

Analisis faktor eksternal (EFAS) ketiga produk olahan apel digabungkan jadi satu, dengan pertimbangan bahwa secara eksternal ketiga produk yang dihasilkan oleh UKM tersebut menghadapi kondisi lingkungan eksternal bisnis yang sama. Sumber analisis adalah penilaian keadaan eksternal oleh kedua produsen olahan apel. Hasil detil analisis EFAS terdapat pada tabel 6 .

\section{Diagram SWOT}

Titik koordinat pada diagram SWOT ditentukan dengan menghitung selisih antara skor kekuatan dan kelemahan (sebagai sumbu
X) dan selisih antara peluang dan ancaman (sebagai sumbu Y). Hasil analisis IFAS menunjukkan bahwa selisih kekuatan dan kelemahan pada produk keripik apel, jenang apel, dan sari apel masing-masing sebesar $+0,60 ;+0,50 ;-0,40$. Sedangkan selisih peluang dan ancaman untuk ketiga produk olahan apel adalah sebesar $+0,83$. Dengan demikian, posisi pada diagram SWOT adalah produk keripik apel dan jenang apel pada kuadran I, sedangkan posisi sari apel pada kuadran III.

Berdasarkan analisis SWOT, posisi bisnis keripik apel (KA) dan jenang apel (JA) berada pada kuadran I, yakni kekuatan lebih besar dari kelemahan. Keripik apel 
Rahayu R., Istis B., Bambang Y. A. : Analisis Swot Untuk Pengembangan Strategi ...

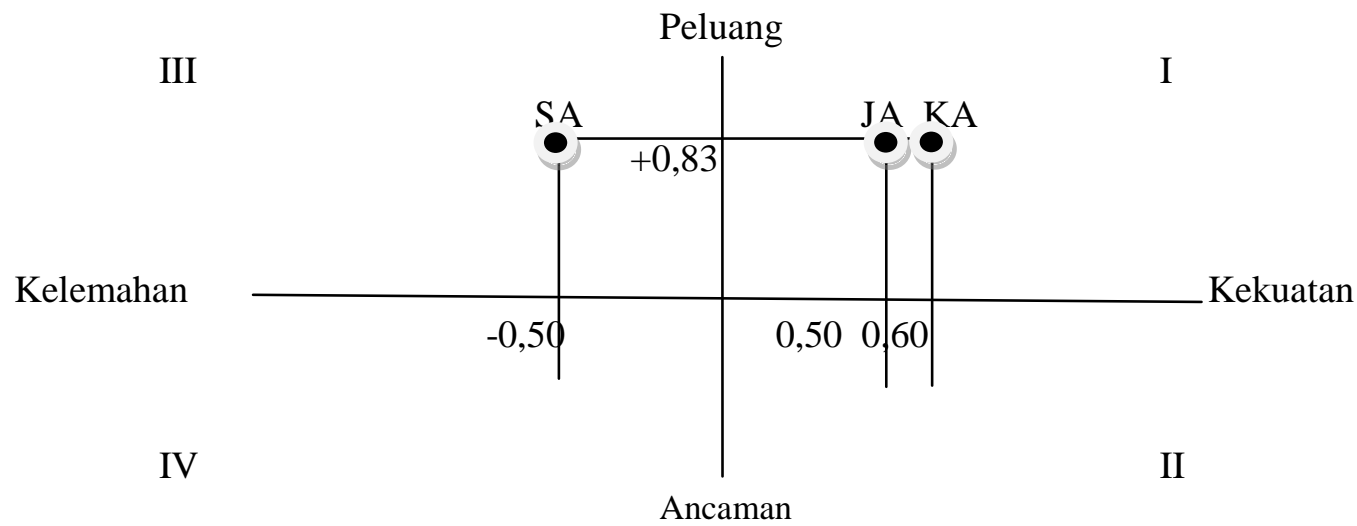

Gambar 2. Diagram SWOT

mempunyai selisih kekuatan sebesar $+0,60$ dan jenang apel mempunyai selisih kekuatan sebesar $+0,50$. Sementara itu sari apel (SA) berada pada kuadran III dengan selisih kelemahan sebesar -0,50. Ketiga produk mempunyai posisi sama dalam hal selisih kesempatan dengan ancaman yakni sebesar $+0,83$. Posisi pada kuadran SWOT produk olahan apel ini berbeda dengan posisi produk agribisnis on farm yakni jeruk keprok Soe yang berada di kuadran II (Namah \& Sinlae, 2012). Dengan demikian strategi bisnis yang digunakan juga berbeda.

Sesuai dengan posisi pada diagram SWOT, pemasaran keripik apel dan jenang apel yang berada di kuadran II berarti harus melakukan strategi SO (agresif), sedangkan pemasaran sari apel harus melakukan strategi yang berbeda yakni strategi WO yakni bertahan (Rangkuti, 2006). Pada strategi SO, produsen keripik apel dan jenang apel harus menggunakan kekuatan yang dimiliki untuk memanfaatkan secara maksimal kesempatan yang ada. Sedangkan pada strategi WO, produsen sari apel harus menggunakan kesempatan yang ada untuk meminimalkan kelemahan yang dimiliki.

\section{Rumusan strategi pemasaran produk olahan apel}

Strategi pemasaran secara detil diuraikan pada masing-masing jenis produk. Penyajian strategi pemasaran keripik apel dan jenang apel digabungkan dalam satu bahasan karena kedua produk mempunyai strategi umum yang sama yakni agresif. Sedangkan strategi pemasaran sari apel disajikan terpisah, karena strateginya berbeda yakni bertahan.
6.1.Produk keripik apel dan jenang apel

Strategi pemasaran yang harus dilakukan produsen keripik apel adalah strategi agresif (menyerang). Bisnis keripik apel harus memanfaatkan kekuatan yang dimiliki untuk memanfaatkan peluang yang ada. Keunggulan kualitas produknya merupakan modal untuk meningkatkan penjualan melalui kerjasama dengan biro perjalanan wisata, hotel dan tempat-tempat seminar/pelatihan yang sering didatangi orang dari berbagai daerah (S1, S2, S3, S4, O2, O3). Rumusan strategi pemasaran tetap harus mempertimbangkan bahwa informasi produk yang diterima konsumen yang dominan adalah berupa informasi lisan. Oleh karena itu kesan konsumen aktual (yang sudah membeli produk) tentang kualitas produk, harga dan tempat pembelian harus baik, karena mereka adalah media promosi yang efektif untuk produk ini.

Kerjasama dengan biro-biro perjalanan wisata dapat dilakukan dengan menawarkan paket oleh-oleh dengan berbagai variasi harga, mengingat tingginya minat konsumen tidak selalu berarti bahwa mereka mempunyai daya beli tinggi. Pada umumnya biro perjalanan wisata bekerjasama dengan toko oleh-oleh khas Malang Raya. Namun tidak tertutup kemungkinan bahwa diantara peserta wisata juga ada yang lebih nyaman berbelanja ketika ada penjual oleh-oleh yang datang ke hotel dimana mereka menginap.

Kerjasama dengan hotel juga dapat dilakukan dengan menyediakan paket oleholeh. Caranya dengan memajang sejumlah sampel paket oleh-oleh, untuk sewaktu-waktu dapat dipesan antar dalam jangka waktu sebelum tamu hotel chek out. Jika memungkinkan display produk di hotel 
tersedia cukup space, maka dapat dilakukan penjualan langsung di outlet hotel.

Sesama produsen olahan apel dapat bekerjasama dalam membuat paket oleh-oleh $(\mathrm{S} 1, \mathrm{~S} 2, \mathrm{~S} 3, \mathrm{~S} 4, \mathrm{O})$. Kerjasama ini memungkinkan konsumen dapat membeli beberapa variasi produk. Hal ini biasanya sudah dilakukan toko oleh-oleh, tetapi produsen olahan apel yang mempunyai produk unggul dapat juga "menjemput konsumen" melalui jalur selain toko oleh-oleh yang sudah umum dilakukan.

Meskipun punya terobosan penjualan sendiri, pemasaran dengan sistem konsinyasi yang selama ini sudah dilakukan pada toko oleh-oleh harus tetap dilakukan bahkan harus ditingkatkan (S6, O4, O5). Strategi ini mengingat tempat pembelian sudah dinilai baik oleh konsumen (S6). Caranya adalah dengan mengatur sistem diskon, misalnya dengan pemberian diskon jika pembeli membeli dengan jumlah minimum tertentu. Misalnya jika membeli sepuluh bungkus produk keripik apel maka harga didiskon 5\%. Cara ini direkomendasikan mengingat salah satu kelemahan produk ini adalah tidak adanya diskon (W1), meskipun disisi lain kekuatannya adalah harga yang terjangkau (S5).

Strategi perluasan jaringan pasar pasti memerlukan dukungan dana. Jika aset tunai yang dimiliki tidak cukup untuk mendanai perluasan pasar, dapat digunakan adanya tawaran kredit bank (O1). Selain itu perluasan pasar juga membutuhkan konsekwensi peningkatan produksi. Mengingat kapasitas produksi yang dimiliki masih terbatas (W2), maka tawaran kredit bank juga dapat digunakan untuk membeli mesin baru dengan kapasitas lebih besar.

\subsection{Produk sari apel}

Strategi pemasaran yang harus dilakukan produsen sari apel adalah strategi bertahan (defensif). Hal ini penting diperhatikan mengingat posisi pada diagram SWOT terletak pada kuadran III, dimana kekuatan lebih kecil daripada kelemahannya, dan kesempatan lebih besar dari ancamannya. Cara pelaksanaan strategi defensif adalah dengan menggunakan kesempatan yang ada untuk meminimalisir kelemahan yang dimiliki.

Produk sari apel termasuk kategori minuman instant. Kelemahan produk menurut pandangan konsumen adalah harga per cup cukup mahal dibandingkan produk sejenis dari merek lain yang mempunyai volume $140 \mathrm{ml}$ per cup. Sehingga konsumen memberikan penilaian/skor rendah pada kesesuaian antara volume dengan harganya. Strategi pemasaran harus mengelola minat konsumen yang masih tinggi terhadap oleh-oleh khas Malang Raya.

Konsumen juga menilai bahwa produk ini mempunyai kelemahan karena tidak tahan lama, namun mereka tidak menginginkan adanya bahan pengawet makanan yang berbahaya bagi kesehatan. Konsekuensi dari penilaian ini adalah konsumen tidak mau membeli produk sari apel dalam jumlah besar. Mereka membeli sari apel dalam jumlah besar hanya jika ada keperluan menjamu tamu dengan minuman instan yang praktis, seperti pada acara hajatan keluarga atau hari raya. Oleh karena itu jumlah permintaan sari apel dirasakan produsen meningkat cukup banyak misalnya saat menjelang hari raya. Sebagai contoh seorang responden membeli minuman sari apel cukup 1 kardus untuk satu bulan, tapi menjelang hari raya dia membeli sari apel hingga lima kardus.

Produsen harus benar-benar menjaga kualitas produk. Salah satu penyebab tidak awetnya produk adalah kemasan cup bisa menggelembung, yang mengindikasikan adanya bakteri berkembang dalam kemasan cup. Oleh karena itu proses sterilisasi cup, higienis produk dan proses pengemasan harus benar-benar menjaga kualitas produk. Jika suatu merek sari apel dikenali konsumen mengalami penggelembungan cup, maka selamanya konsumen tidak lagi mau membeli produk tersebut.

Kelemahan jaringan pasar terbatas juga terkait dengan karakteristik produk yang dinilai tidak awet oleh konsumen. Oleh karena itu pasar dominan sementara ini masih di seputar pusat oleh-oleh produk di Malang Raya. Strategi yang harus dilakukan adalah memelihara hubungan baik dengan rekanan pemasaran yakni pusat oleh-oleh, produsen parcel dan catering. Khusus relasi dengan pengusaha catering, kemasarn produk bisa dimodifikasi misalnya dengan kemasan botol besar atau galon, untuk memungkinkan dihidangkan dalam dengan wadah jar besar, bukan dalam cup kecil. 
Rahayu R., Istis B., Bambang Y. A. : Analisis Swot Untuk Pengembangan Strategi ...

Berbagai media informasi harus digunakan secara optimal untuk kepentingan promosi produk oleh-oleh Malang Raya ini. Sebanyak $43 \%$ konsumen menerima informasi tentang produk ini dari media promosi. Oleh karena itu televisi lokal di Malang Raya, website resmi pemerintahan (Pemkab/Pemkot, Dinas Perindustrian dan Perdagangan) harus dimanfaatkan sebagai media informasi dan promosi produk khas Malang Raya ini.

Terkait dengan isi informasi, konsumen harus menerima informasi yang benar, dengan demikian produsen harus melakukan etika bisnis yang bertanggungjawab. Misalnya, produsen hanya menggunakan bahan tambahan makanan yang diijinkan untuk makanan dan minuman, seperti pemanis dan pengawet. Perlu diingat bahwa konsumen memberikan kelemahan pada aspek pengawet makanan. Artinya mereka sudah peduli dengan keamanan pangan. Jika produsen tidak memberikan perhatian pada aspek ini maka sulit untuk mempertahankan keberlanjutan bisnis.

\section{KESIMPULAN DAN SARAN}

Olahan apel secara umum mempunyai kekuatan pada aspek produk, terutama pada indikator rasa yang dinilai konsumen enak dan ada cita rasa khas apel. Namun beberapa kelemahan produk juga harus menjadi perhatian produsen, diantaranya adalah produk kurang tahan lama namun konsumen juga tidak menginginkan adanya bahan pengawet. Peluang yang dihadapi adalah tingginya minat konsumen, banyak toko oleh-oleh dan tawaran kredit bank. Ancaman terdiri dari persaingan bisnis yang tidak sehat dan lemahnya daya beli konsumen meskipun mereka berminat terhadap produk. Berdasarkan SWOT, strategi pemasaran yang direkomendasikan pada produk keripik apel dan jenang apel adalah strategi agresif, sedangkan produk sari apel direkomendasikan menjalankan strategi defensif.

Konsumen sudah mulai peduli dengan keamanan pangan, sehingga mereka tidak menginginkan produk olahan yang diberikan bahan makanan tambahan yang berbahaya. Terkait hal ini, produsen harus memberikan informasi yang benar dan beretika bisnis, dengan memanfaatkan berbagai media informasi secara optimal untuk kepentingan promosi produk olahan apel.

\section{DAFTAR PUSTAKA}

Bhattacherjee, A. (2012). Social Science Research: Principles, methods, and practices. Global Text Project. doi:10.1186/1478-4505-9-2

Darmansyah, A., Rochana, S. H., Sutardi, A., \& Zuraida, U. (2014). The New Growth Centres and Strategy for Building and Accelerating Agribusiness Development in Cirebon Regency, Indonesia. Procedia - Social and Behavioral Sciences, 115(Iicies 2013), 296-304. doi:10.1016/j.sbspro.2014.02.437

Ioan, S., \& Cristin, I. (2014). A Broad Analysis of Marketing Strategies for their Incorporation as Activities in a User Centred Process. Procedia Economics and Finance, 16(May), 239-250. doi:10.1016/S2212-5671(14)00797-7

Kotler, P., \& Armstrong, G. (2012). 14 Ed. Principles of Marketing (14th ed.). Pearson Prentice Hall.

Namah, C. N., \& Sinlae, D. V. (2012). The Feasibility Study of Keprok SoE Citrus Farming and the Development Strategis of Local Citrus Farming. Procedia Economics and Finance, 4(Icsmed), 8696. doi:10.1016/S2212-5671(12)00324-3

Porter, M. E. (1998). COMPETITIVE STRATEGY Techniques for Analyzing Industries and Competitors. With New A Introduction. New York: The Free Press.

Rangkuti, F. (2006). Analisis SWOT Teknik Membedah Kasus Bisnis. Jakarta: PT. Gramedia Pustaka Utama.

Shariatmadari, M., Homayoun, A., \& Hedayat, P. (2013). Using SWOT analysis and SEM to prioritize strategies in Foreign exchange market in Iran. Procedia Social and Behavioral Sciences, 99, 886-892. doi:10.1016/j.sbspro.2013.10.561 
Rahayu R., Istis B., Bambang Y. A. : Analisis Swot Untuk Pengembangan Strategi ...

Wan-rong, G., Yi, J., Yao, M., Jian-guo, W., Xian-long, Z., Jing, L., \& Shi, W. (2013). SWOT Analysis and Development Strategies of Maize
Industry in Heilongjiang Province. Journal of Northeast Agricultural University, 20(1), 76-84. doi:10.1016/S1006-8104(13)60013-6 